\title{
AKSEPTABILITAS DAN PEMANFAATAN PIK-R (PUSAT INFORMASI KONSELING-REMAJA) SISWA SMA DI KOTA DENPASAR
}

\author{
${ }^{1}$ Agustini, Ni Komang Tri ${ }^{2}$ Ida Ayu Ningrat Pangruating Diyu \\ ${ }^{12}$ Institut Teknologi dan Kesehatan Bali
}

Korespondensi: agustini.komang90@gmail.com

\begin{abstract}
Background: Health problem that often experienced by adolescent is reproductive health. PIK-R (Pusat Informasi Konseling-Remaja) or Youth Information and Counseling Center is program to provide information about reproductive health counseling. Beside the facilities of PIK-R in school, acceptability and utilization of PIK-R by students is an important factor to support this program. The aim of this study was to identified acceptability and utilization to PIK-R in school in Denpasar. Methods: The study used cross sectional design. Subjects were 158 high school students. Data were obtaining used questionnaire and analyzed used chi-square. Result: The result of univariate analysis showed the acceptability of students was 97 $(61,4 \%)$ and the utilization was $53(33,5 \%)$. The utilization of PIK-R in school was associated with acceptability $\left(x^{2}=4,26, p=.03\right)$. Conclusion: Students who were accepted PIK-R program also utilize this program as reproductive health information centre.
\end{abstract}

Keyword: Youth Information and Counseling Center, acceptability, utilization ABSTRAK

Latar Belakang: Masalah kesehatan yang menonjol di kalangan remaja adalah masalah kesehatan reproduksi. PIK-R (Pusat Informasi Konseling-Remaja) adalah salah satu upaya menyediakan informasi serta konseling remaja mengenai kesehatan reproduksi yang ada di sekolah. Akseptabilitas dan pemanfaatan oleh siswa merupakan faktor penting untuk mendukung program PIK-R. Tujuan dari penelitian ini adalah untuk mengetahui akseptabilitas dan pemanfaatan PIK-R pada siswa SMA di Kota Denpasar. Metode: Penelitian ini merupakan penelitian cross sectional. Responden penelitian ini adalah 158 siswa SMA di Kota Denpasar. Data diperoleh melalui kuesioner dan dianalisis dengan chi-square. Hasil: Hasil univariate menunjukkan sebanyak $97(61,4 \%)$ siswa menerima akan PIK-R dan pemanfaatannya sebanyak 53 $(33,5 \%)$. Terdapat hubungan yang bermakna antara akseptabilitas degan pemanfaatan PIK-R dengan nilai korelasi $\left(x^{2}=4,26, p=.03\right)$. Kesimpulan: Siswa yang menerima PIK-R memanfaatkan PIK-R sebagai pusat informasi kesehatan reproduksi

Kata Kunci: PIK-R (Pusat Informasi Konseling-Remaja), akseptabilitas, pemanfaatan 


\section{PENDAHULUAN}

Permasalahan remaja merupakan hal yang patut menjadi sorotan saat ini, hal ini dikarenakan remaja merupakan periode transisi yang akan menimbulkan berbagai masalah. Menurut BKKBN (2012) masalah yang menonjol di kalangan remaja yaitu permasalahan seputar Triad Kesehatan Reproduksi Remaja (KRR) yaitu seksualitas, HIV/AIDS dan Napza. Hasil Survei Demografi Kesehatan Indonesia (SDKI) 2012 Kesehatan Reproduksi Remaja (KRR) menunjukkan bahwa 9,3\% remaja menyatakan pernah melakukan hubungan seksual pranikah. Berdasarkan data dari Badan Narkotika Nasional (BNN) tahun 2014, sebanyak $27,32 \%$ pelajar adalah penggguna Napza. Rendahnya pengetahuan remaja tentang kesehatan reproduksi belum memadai yang dapat dilihat dengan hanya 35,3\% remaja perempuan dan 31,2\% remaja laki-laki usia 15-19 tahun mengetahui bahwa perempuan dapat hamil dengan satu kali berhubungan seksual. Pengetahuan remaja tentang Infeksi Menular Seksual (IMS) masih rendah dimana hanya $35 \%$ wanita dan $19 \%$ pria mengetahui gonorrhea, $14 \%$ wanita dan $4 \%$ pria mengetahui genital herpes sedangkan jenis IMS lain dibawah $1 \%$.

Dalam rangka mengemban amanat undang-undang dan merespon permasalahan remaja, BKKBN mengembangkan program Kesehatan Reproduksi Remaja (KRR) sekaligus membentuk wadah kegiatan tersebut dengan prinsip pengelolaan dari, oleh dan untuk remaja yang diberi nama Pusat Informasi dan Konseling Kesehatan Reproduksi Remaja (PIK KRR) pada tahun 2006. PIK-R dengan program PKBR (Penyiapan Kehidupan Berkeluarga bagi Remaja) nya sekarang ini diharapkan mampu memfasilitasi terwujudnya "Tegar Remaja" yakni remaja yang tidak saja berperilaku sehat namun terhindar dari risiko Triad KRR (Seksualitas, HIV/AIDS dan Napza). Keberadaan konselor sebaya, media informasi, dan metode pemberian informasi dalam PIK-R dapat meningkatkan pengetahuan remaja (Sotolongo, et.al 2007). Anjarwati et al (2010) dalam penelitiannya menunjukkan bahwa 83,3\% siswa belum pernah memanfaatkan jasa pelayanan dari pusat kesehatan reproduksi remaja. Berdasarkan data Disdikpora, saat ini di Kota Denpasar terdapat 61 SMP, 29 SMA/SMK, dan 29 Perguruan Tinggi, namun tidak semuanya memiliki PIK-R. 
Masalah kesehatan reproduksi remaja sebenarnya tidak hanya tergantung pada ketersediaan fasilitas pelayanan kesehatan, tetapi juga oleh kemauan remaja untuk mencari pelayanan kesehatan reproduksi. Pemanfaatan pelayanan kesehatan reproduksi remaja masih tergolong rendah. Tujuan penelitian ini adalah mengetahui akseptabilitas dan pemanfaatan PIK-R (Pusat Informasi Konseling-Remaja pada siswa SMA di Kota Denpasar.

\section{METODE}

Penelitian ini merupakan penelitian cross sectional. Penelitian ini dilaksanakan di SMA yang telah memiliki program PIK-R di Kota Denpasar (SMAN 2 Denpasar, SMAN 8 Denpasar dan SMA Dharma Praja) pada bulan Januari 2019. Pemilihan sampel ditentukan dengan menggunakan teknik sampling non-probability sampling yaitu purposive sampling, dengan memilih sampel berdasarkan tujuan penelitian yang sesuai kriteria inklusi. Kriteria inklusi dalam penelitian ini adalah : 1) siswa SMA aktif kelas XI, 2) tidak berstatus sebagai pendidik sebaya (peer counselor) 3) bersedia menjadi responden 4) bisa membaca dan menulis dalam Bahasa Indonesia. Perhitungan besar sample ini menggunakan software Sample Size Determination in Health Studies Version 2.00 Copy Right (c) 1996-98, World Health Organization. Tingkat kepercayaan yang digunakan $99 \%$ dan power $80 \%$ diperoleh sample sebesar 142 responden. Hasil tersebut ditambahkan 10\% dari besar sample, maka jumlah responden yang digunakan adalah 156 responden. Kuesioner yang digunakan adalah Kuisioner yang berisi pertanyaan Akseptabilitas dan pemanfaatan PIK-R yang terdiri dari 14 pertanyaan yang telah disusun oleh Afrima (2011) dan dilakukan uji validitas dan reliabilitas dengan nilai alpha 0,977 . 


\section{HASIL}

Tabel 1 Distribusi karakteristik sampel berdasarkan umur dan jenis kelamin siswa SMA di Kota Denpasar

\begin{tabular}{lcc}
\hline Variable & $\boldsymbol{F}$ & $\%$ \\
\hline Jenis kelamin & 77 & 48,7 \\
- Laki-laki & 81 & 51,3 \\
$-\quad$ Perempuan & & \\
Umur & 9 & 5,7 \\
$-\quad 15$ tahun & 61 & 43,7 \\
-16 tahun & 75 & 47,5 \\
-17 tahun & 4 & 2,5 \\
-18 tahun & 1 & 0,6 \\
-21 tahun & & \\
\hline
\end{tabular}

Pada Tabel 1 didapatkan karakteristik responden sebagian besar perempuan sebesar 81 (51,3\%) dan laki-laki sebanyak 77 (48,7\%). Dilihat dari umur sebagian besar responden berumur 17 tahun sebanyak 75 (47,5\%), berumur 16 tahun sebanyak 61 (43,7\%), berumur 15 tahun sebanyak $9(5,7 \%)$, berumur 18 tahun sebanyak 4 (2,5\%) dan 1 responden $(0,6 \%)$ berumur 21 tahun.

Tabel 2 Tabel frekuensi variable penelitian (akseptabilitas dan pemanfaatan terhadap PIKR) pada siswa SMA di Kota Denpasar

\begin{tabular}{lrl}
\hline Variable & $\boldsymbol{F}$ & $\%$ \\
\hline Akseptabilitas & & \\
- Menerima & 97 & 61,4 \\
- Tidak menerima & 61 & 38,6 \\
Pemanfaatan & & \\
- Memanfaatkan & 53 & 33,5 \\
- Tidak memanfaatkan & 105 & 66,5 \\
\hline
\end{tabular}

Pada tabel 2 didapatkan dari 158 responden, sebanyak 97 (61,4\%) siswa menerima akan adanya PIK-R. Namun dilihat dari pemanfaatannya sebagian besar mahasiswa 
tidak memanfaatkan yakni sebanyak 105 (66,5\%) dan yang memanfaatkan hanya $53(33,5 \%)$.

Tabel 3 Tabel tabulasi silang jenis kelamin dengan akseptabilitas PIK-R pada siswa SMA di Kota Denpasar

\begin{tabular}{lllllll}
\hline Jenis kelamin & \multicolumn{9}{c}{ Akseptabilitas PIK-R } \\
\cline { 2 - 7 } & \multicolumn{2}{l}{ Menerima } & \multicolumn{2}{c}{ Tidak Menerima } & Total & \\
\cline { 2 - 7 } & $\boldsymbol{F}$ & $\mathbf{\%}$ & $\boldsymbol{F}$ & $\boldsymbol{\%}$ & $\boldsymbol{F}$ & $\boldsymbol{\%}$ \\
\hline Laki-laki & 44 & 27,8 & 33 & 20,9 & 77 & 48,7 \\
Perempuan & 53 & 33,5 & 28 & 17,7 & 81 & 51,3 \\
Total & 97 & 61,4 & 61 & 38,6 & 158 & 100 \\
\hline
\end{tabular}

Tabel 3 menunjukkan bahwa responden laki-laki yang menerima akan keberadaan PIK-R sebanyak 44 (27,8\%), sedangkan yang tidak menerima sebanyak 33 (20,9\%). Responden perempuan yang menerima akan PIK-R sejumlah 53 (33,5\%) dan yang tidak menerima sebanyak $28(17,7 \%)$.

Tabel 4 Tabel tabulasi silang jenis kelamin dengan pemanfaatan PIK-R pada siswa SMA di Kota Denpasar

\begin{tabular}{lllllll}
\hline Jenis kelamin & \multicolumn{7}{c}{ Akseptabilitas PIK-R } & & \\
\cline { 2 - 7 } & \multicolumn{2}{l}{ Memanfaatkan } & \multicolumn{2}{l}{ Tidak Memanfaatkan } & Total & \\
\cline { 2 - 7 } & $\boldsymbol{F}$ & $\boldsymbol{\%}$ & $\boldsymbol{F}$ & $\boldsymbol{\%}$ & $\boldsymbol{F}$ & $\boldsymbol{\%}$ \\
\hline Laki-laki & 33 & 20,9 & 44 & 27,8 & 77 & 48,7 \\
Perempuan & 20 & 17,7 & 61 & 38,6 & 81 & 51,3 \\
Total & 53 & 33,5 & 105 & 66,5 & 158 & 100 \\
\hline
\end{tabular}

Tabel 4 dapat dilihat sebanyak 33 (20,9\%) responden laki-laki memanfaatkan PIK-R dan sebanyak $44(27,8 \%)$ responden tidak memanfaatkan PIK-R. Responden perempuan sebanyak $20(17,7 \%)$ memanfaatkan PIK-R dan sebanyak 61 (38,6\%) tidak memanfaatkan PIK-R. 
Tabel 5 Tabel analisis pemanfaatan PIK-R dengan akseptabilitas PIK-R pada siswa SMA di Kota Denpasar

\begin{tabular}{|c|c|c|c|c|}
\hline \multirow{2}{*}{ Variabel } & \multicolumn{2}{|c|}{ Pemanfaatan PIK-R } & \multirow{2}{*}{$x^{2}$} & \multirow{2}{*}{$p$} \\
\hline & Memanfaatkan (\%) & Tidak Memanfaatkan (\%) & & \\
\hline Akseptabilitas & & & 4,26 & .03 \\
\hline Menerima & $39(24,7)$ & $58(36,7)$ & & \\
\hline Menolak & $14(8,9)$ & $47(29,7)$ & & \\
\hline
\end{tabular}

Hasil penelitian menunjukkan sebanyak 97 (61,4\%) siswa menerima keberadaan PIKR. Penerimaan remaja akan adanya PIK-R mampu memberikan manfaat untuk remaja itu sendiri, yakni salah satunya adalah peningkatan pengetahuan kesehatan reproduksi melalui pemberian informasi kesehatan reproduksi.

\section{PEMBAHASAN}

Informasi yang memadai akan membantu remaja untuk mengatasi persoalan seharihari. Pengetahuan kesehatan reproduksi akan mempengaruhi cara berperilaku remaja. Semakin baik pengetahuan remaja maka semakin kecil kecenderungan remaja untuk melakukan perilaku beresiko. Untuk mencegah perilaku beresiko maka remaja perlu diberikan penyuluhan, pendidikan dan informasi yang benar mengenai kesehatan reproduksi sehingga remaja tidak akan memperoleh informasi yang menyesatkan (Suhartati, 2008). Seseorang akan memanfaatkan pelayanan kesehatan jika menyadari bahwa pelayanan kesehatan adalah suatu yang dibutuhkan, begitu juga bagi remaja. Jika remaja menyadari bahwa pelayanan kesehatan reproduksi adalah suatu hal yang penting maka remaja akan memanfaatkan pelayanan kesehatan reproduksi. Namun dilihat dari pemanfaatannya sebagian besar mahasiswa tidak memanfaatkan yakni sebanyak $105(66,5 \%)$.

Menurut hasil penelitian Vingilis et al. (2007) menemukan bahwa penyebab utama remaja memanfaatkan pelayanan kesehatan, baik karena keluhan fisik maupun psikologis adalah karena kebutuhan akan informasi tentang pendidikan kesehatan reproduksi. Hasil penelitian Agustini (2018) memaparkan bahwa kurangnya pemanfaatan pelayanan kesehatan reproduksi pada remaja karena masih banyak yang menganggap bahwa informasi yang diberikan khususnya kesehatan reproduksi adalah masalah tabu untuk dibicarakan, sehingga 
remaja enggan untuk mencari tahu informasi tersebut. Menurut Usnawati \& Zainafree (2014) seseorang yang memiliki perilaku beresiko cenderung menilai bahwa layanan kesehatan reproduksi remaja tidak penting karena bisa mengakses informasi secara bebas melalui media massa maupun internet. Selain itu, remaja menganggap masalah seksualitas dan kesehatan reproduksi adalah hal yang tabu untuk dibicarakan. Hal inilah yang justru menyebabkan makin rumitnya permasalahan yang dihadapi oleh remaja karena tidak terdapat penanganan terhadap masalah tersebut. Perilaku seksual adalah hal yang sangat sensitif sehingga tidak jarang mereka menutup-nutupinya meskipun itu bermasalah.

Remaja yang datang ke fasilitas kesehatan untuk mendapatkan informasi dan konseling remaja lebih menerima terhadap pelayanan yang diberikan kepada remaja (Kamau, 2006). Hasil penelitian ini juga diperkuat oleh WHO (2002) yang menyatakan bahwa kurangnya pemanfaatan pelayanan kesehatan reproduksi remaja disebabkan dari sikap dari penyedia pelayanan yang kurang dapat menerima remaja. Remaja mempunyai penilaian terhadap system pelayanan kesehatan yang akan mereka manfaatkan. Penilaian tersebut akan menimbulkan suatu sikap penerimaan atau penolakan terhadap pelayanan kesehatan reproduksi.

Hasil penelitian membuktikan bahwa terdapat hubungan antara akseptabilitas PIK-R dengan pemanfaatan PIK-R oleh siswa di SMA di Kota Denpasar $\left(x^{2}=4,26, p=.03\right)$. Banyak faktor yang dapat mempengaruhi pemanfaatan pelayanan kesehatan reproduksi remaja, salah satunya adalah pelayanan kesehatan yang diberikan. Apabila pelayanan kesehatan yang diberikan mampu diterima dengan baik oleh remaja, maka remaja akan memanfaatkan fasilitas kesehatan dengan baik. Dalam menghadapi remaja diperlukan peran petugas kesehatan yang peduli remaja yang mengerti akan permasalahan remaja. Remaja dalam memanfaatkan pelayanan kesehatan reproduksi tidak hanya tergantung pada ketersediaan fasilitas, tetapi juga kemauan remaja untuk mencari pelayanan kesehatan. Pada umumnya remaja yang berkunjung ke pelayanan kesehatan reproduksi membutuhkan privacy saat memanfaatkan pelayanan kesehatan reproduksi.

\section{KESIMPULAN}

Siswa menerima keberadaan PIK-R dan memanfaatkan PIK-R sebagai pusat informasi 
kesehatan reproduksi. Akan tetapi, masih banyak siswa yang belum memanfaatkan layanan PIK-R.

\section{DAFTAR PUSTAKA}

Afrima, A. (2011) Akseptabilitas Pusat Indormasi dan Konsultasi Kesehatan Remaja Pada Siswa SMU di Kota Bima. Tesis Minat Kesehatan Ibu dan Anak Kesehatan Reproduksi. Fakultas Kedokteran Universitas Gadjah Mada

Agustini, N,K,T. (2018) Kompetensi Sosial Konselor Sebaya dalam melakukan konseling di Sekehe Truna Truni. Tesis Minat Keperawatan Maternitas. Fakultas Kedokteran, Kesehatan Masyarakat dan Keperawatan Universitas Gadjah Mada

Anjarwati, Wulandari \& Armi. (2010). Pengaruh Penyuluhan Tentang Kesehatan Reproduksi Remaja Terhadap Sikap Seks Pranikah pada Remaja di Kampung Gambiran Yogyakarta Tahun 2010. Thesis. STIKES Aisyiyah Yogyakarta

BKKBN. 2012. Pedoman Pelaksanaan Pengelolaan Pusat Indormasi dan Konseling Remaja dan Mahasiswa (PIK R/M), Jakarta: BKKBN

Vingilis, E., Wadeb, T. \& Seeleya, J. (2007) Predictors of Adolescent Health Care Utilization. Journal of Adolescent

Kamau, A.W. (2006) Factors influencing access and utilization of preventive reproduction health services by adolescent in Kenya. Dissertation. Faculty of Health Sciences, School of Public Health. Germany: University of Bielefeld

Sotolongo, J.S., House, M., Duane, L., Swanson, S. 2017. Integrated Community Strategies for Linking Youth to Adolescent Reproductive Health Services : A Case Study. Journal of Adolescent Health, 60(3), pp.S45-S50. Available at: http://dx.doi.org/10.1016/j.jadohealth.2016.11.026

Suhartati. (2008) Pelayanan Kesehatan Reproduksi Remaja dan Pemanfaatannya di Puskesmas Kabupaten KotaBaru Kalimantan Selatan. Tesis. Minat Kesehatan Ibu dan Anak-Kesehatan Reproduksi, Program Studi Ilmu Kesehatan Masyarakat. Yogyakarta: UGM

Usnawati, U., \&Zainafree, I. (2014). Studi Kualitatif Motivasi Wanita Pekerja Seks (WPS) di sepanjang ruas jalan stasiun Poncol untuk mengikuti Voluntary Counselling and Testing (VCT). Unnes Journal of Public Health, 2(4). Retrieved from https://journal.unnes.ac.id/sju/index.php/ujph/article/view/5518

WHO (2002) Adolescent Friendly Services: An Impact Model to evaluate their Effectiveness and Cost. Manchester, United Kingdom: WHO 
Bali Health Published Journal Vol.1 No.2 